\title{
Looking down, staying with and moving along: Towards collaborative ways of knowing with nature in the Anthropocene
}

Gunnar Thór Jóhannesson, University of Iceland

\section{Introduction}

This research note is about collaborative ways of knowing with nature in the Anthropocene. I am interested in exploring some of the ways we can use to think about our relations to nature and how we might enact those in our efforts of knowledge creation. The notion of the Anthropocene underlines that society and nature are closely entwined contrary to what the traditional separation between social and natural sciences tends to portray. I will argue that it is crucial for us to move beyond the common divide between the two in order to create response-able knowledge through our research and education. We need to appreciate that the social is not only about human-to-human relations but human-to-more than human relations. It is emergent through multiple webs of relations, where humans and more-than humans co-mingle, co-create and collaborate. The concept of co-creation is indeed one of the buzz words in university policy at the moment and is as such shaping the realities of education and research. But has it any meaning in relation to the Anthropocene? What might it mean to be part of the earth and thus to engage in collaborative ways of creating knowledge with nature? To be honest, I do not have any affirmative answer but here I will discuss three tropes or actions that I think can be useful to render collaborative ways of knowing with nature meaningful, namely: looking down, staying with and moving along. 


\section{Co-creation in the Anthropocene}

If travel is searching

And home what's been found

I'm not stopping

I'm going hunting

I'm the hunter

I'll bring back the goods

But I don't know when

I thought I could organise freedom

How Scandinavian of me.

(Björk Guðmundsdóttir (Björk), 1997. Hunter.)

This is the first half of the lyrics of one of my favourite songs, Hunter, by Björk. We all relate differently to music and poetry and in the case of this song, what sparked my interest in it were the last two lines: "I thought I could organise freedom, how Scandinavian of me". I remember I listened a lot to this song during a period when working on my PhD. I was writing about Actor-Network Theory and tourism and how tourism realities emerge through heterogeneous ordering. They are co-created by many different actors, human and more than human (Jóhannesson, 2007). However, as many ANT-inspired studies have shown, ordering is quite precarious work. There is always something 'out of order' so to say and it takes a lot of effort to keep a particular order up and running (Latour, 2002; van der Duim, Ren, \& Jóhannesson, 2012). Cracks may open any time and sometimes quite suddenly and dramatically as in the case of the Eyjafjallajökull volcano eruption in 2010 that seriously affected air transport in Europe (Lund \& Benediktsson, 2011). What happened? Ash particles met jet engines in high altitude with serious implications for various ordering of mobilities. This was not a good encounter for tourism at all. The song, for me at least, highlights that no order is perfect and we as humans - even if we are Scandinavians - are never in total control of things. Nature is an unruly force that cannot be contained within any model; order and dis-order are co-created through relations.

This is, probably, not the first example of co-creation that comes to mind. It is more common to relate co-creation to the ways in which producers and consumers of a particular product, experience or service jointly produce it, partly or in whole (e.g. Prahalad \& Ramaswamy, 2004). Value co-creation is also increasingly becoming prominent in the daily business of academia. Often that means in practice that we need to prove the value of our work for communities and businesses "outside" academia. It can be stated that the idea of co-creation is a part of a larger societal discourse tightly related to neo-liberal market and governance practice (Berg \& Seeber, 2016). It relates to a reconfigured relationship between the public and private sector emphasizing competitiveness, individualization and economic reason but also, and that is very important, more relational, complex and collaborative ways of engaging with and assessing values and effects. Most researchers would be happy to collaborate and engage in co-creation, but the problem for many is that co-creation is often quantified and measured and used as a management tool to discipline and shape academia with very material effects. Co-creation is not an innocent 
idea, it is power-laden and political tool highlighting the importance of relational practice for establishing societal order (van der Duim, Jóhannesson, \& Ren, 2018). With that in mind I would like to move on to think about two kinds of relations that matter for us. On the one hand, our relation to nature and, on the other hand, the relations through which we create knowledge.

It has been argued many times before that from the time of the Enlightenment and what Latour (1993) calls the modern episteme nature and culture or humans and environment have been framed as separate entities. Gísli Pálsson (1996) described three modes of relations between humans and the environment more than 20 years ago, namely, orientalism, paternalism and communalism. Starting with the first two, they are both based on a clear separation between nature and society. While orientalism frames humans as the masters of nature and the earth as a passive subject of their desires, paternalism sees humans more as stewards and keepers of the earth and her treasures. Much of the discourse on conservation is based on the idea of nature being a manageable entity if we only have the good or correct knowledge of it. It does not necessarily see humanity as part of nature. A case in point is that often nature is ranked in ways which render some areas or locations seeming more natural than others. Untouched wilderness is seen in this optic as the purest form of nature as it has little or no human influence.

The third mode of human-environment relations Pálsson mentions is communalism. It is different as it does not see nature and society as easily distinctive fields and at the same time it is uncertain that humans have the ability to fully grasp the implications of their activities. This mode situates humans with the earth. It is no longer a passive stage for humans to play out their socially constructed realities but an active force or agent that humans live with. The dichotomy between nature and culture is thereby not given in the order of things but rather created and accomplished through various relations. It is, in other words, a matter of concern but not a matter fact (Latour, 1993, 2004).

This is what the concept of the Anthropocene highlights. It undermines the very constitution of modern sciences that has been based on the idea of separation between nature and society and in many ways contributed to the divide between nature and society. The Anthropocene brings forth that geologies are part of our daily lives, we are entangled in various relations to nature and the earth in very basic terms. In order to describe this entanglement Pálsson and Swanson (2016) propose the concept of geosociality, which, they argue, opens up for ways to include rocks, stones or just minerals in general in the definition of the social. They argue that it is crucial to explore the multiple layers of relations that braid "biographies and earth systems" (p. 167). That is, the multiple ways in which we are in the earth and the earth is in us, in order to render the Anthropocene meaningful. This has various implications for tourism research and education. We have to be able to relate the emergent realities of the Anthropocene and anchor them in our knowledge practices - we have to be able to respond to more messy and uncertain realities than before.

Let us move to knowledge practices and the relations through which we create knowledge. We can usefully think about three common modes of knowledge creation as three modes of relating to nature. As Gísli Pálsson (1996) notes, in the context of anthropology cultural others were often grouped together with nature - both could be investigated and analysed from a distance. 
This is the classical stance of anthropology as Malinowski (1984) framed it. For him the role of the ethnographer was to provide holistic accounts of tribal cultures and ways of life, to convey this knowledge from the field and represent it in the most accurate way as possible in other places, most often at home within academia. The world according to this view is an object of science and the scientist could order and report the natural and social environment with his or her tools and methods. The rise of post-modernism in the 1980 s was indeed a counterpoint towards the positivist ideal but it also disconnected research from the lifeworld and at times reduced lived experiences to textual representation (Pálsson, 1995). Both seemed to deny the possibility of constructing or composing reality that was simultaneously material, cultural and discursive (see e.g. Latour, 2005, 2017).

The question is when we know that scientific facts are constructed, when we know that there is no clear boundary of a field but rather we are always part and parcel of that field, how are we able to construct good - or robust (and critical) knowledge? According to Tim Ingold (2013) it is not enough to collect data for documentary purposes like hard facts and statistics which has been the main project of much of social science. He argues that good research should be about "studying with and learning from; it is carried forward in a process of life, and effects transformations within that process" (Ingold, 2013, p. 3). Ingold (2013, p. 5) argues that "participant observation is a way of knowing from the inside" (emphasis in original). It is an ontological practice and in turn, if we engage in fieldwork and learn from it, it is because we are part of the field.

We, as tourism researchers living the Anthropocene, need to learn to know it from the inside. Or maybe it is better to think of it in terms of topology, where there is no inside or outside (Blok, 2010). Question is therefore not how we may stand outside or inside of the Anthropocene or everyday life for that matter for once and for all but how we might interfere with, move back and forth locations and position ourselves in the midst of multiplicity of geosocial relations to make tourism research matter.

\section{Looking down - staying with - moving along}

Here I would like to propose three ways to engage in collaborative ways of knowing with nature in the Anthropocene, namely: Looking down, staying with and moving along.

The first one refers to the importance of being down to earth. Even though the Anthropocene has highlighted our co-existence with earth, it does so on a particular scale, usually on a planetary or global scale. The Anthropocene is in this sense BIG. Without denouncing the importance of thinking big, it is important to pay attention to other scales or layers as well. As Pálsson and Swanson (2016) remark, the universalism, the Anthropocene implies, has the risk of masking off any difference and sustaining a distinction between global earth systems and local human differences and activities. We need, in other words, to situate the globality of the Anthropocene. In tourism research and education the challenge is to relate our situated knowledge practices to the long and varied relations of the Anthropocene. To link what may seem distant and absent to what is close and present. For the example of an effort to accomplish that I draw on a study of the history of tourism development in Lanzarote (Jóhannesson, Ren, \& van der Duim, 2016). 
In the early 1960s the island authorities in Lanzarote were focusing on tourism development. They invested in infrastructure such as an airport and an installation for the purification of water and the conditions for a limited number of hotels and apartments, as well as seven Centres for Art, Culture and Tourism. In the latter, the artist César Manrique worked along the relations between nature and society in novel ways and created tourism attractions that were difficult to situate either within a pure sphere of nature or culture. This was, for instance, a restaurant and concert-hall situated in a part of a cave, and a museum where volcanic lava flows into the art exhibition. The idea was based on what later was described as the Manrique model - a philosophy of limited growth, respect for local architecture and tourist attractions, in which tourism, nature and culture were architectonically integrated. As time went by, this philosophy came under stress in Lanzarote and elsewhere with the increase in mass tourism, changes in the international aviation system and changes in local government.

While it is possible to describe a case like this in common terms of fragile local place under pressure from global forces of capitalism, it is important to by-pass the divide between big and small, local and global, human and more-than-human and rather follow the links and relations through which tourism in Lanzarote develops. For instance, tourism in Lanzarote is sustained by the earth's potentialities (volcanic landscape and lava). Simultaneously it undeniably contributes to the condition we today term the Anthropocene as all other forms of tourism. It is important to recast tourism as concrete and specific practice and a becoming topological ordering of space. Rather than treat global tourism mobilities or global climate change as hovering above clearly defined places, we need to be able to trace the relations through which these phenomena are accomplished through situated practices. It is important to link tourism to other activities on the ground and take care to attend to how those relations matter differently to particular entities (human and more than human) in particular locales. By looking down we are able to situate tourism and bring forth the geosocial relations the Anthropocene manifests.

Second, we should stay with the trouble (Haraway, 2016). Tourism is not a singular entity; it is a collaborative achievement accomplished through heterogenous relations. It is "becoming with many" (Haraway, 2008, p. 4). However, tourism is still usually defined as a clearly defined sector or an industry, which means that there are countless 'others' that fall out of the assemblage of tourism proper. This includes the earth (Huijbens \& Gren, 2016). Haraway proposes the concept in the context of the emergent reality of the Anthropocene, which highlights that we require each other in unexpected collaborations and combinations (Ren \& Jóhannesson, 2018). Staying with the trouble also urges us to think of future possibilities in terms of "both-and" rather than "either or". To quote Haraway again:

[T] address trouble in terms of making an imagined future safe [...]. Staying with the trouble requires learning to be truly present, not as a vanishing pivot between awful and endemic pasts and apocalyptic or salvific futures, but as mortal critters entwined in myriad unfinished configurations of places, times, matters, meaning (Haraway, 2016, p. 2).

Staying with the trouble forges a middle ground between bi-polar responses to the state of alert of the Anthropocene: resignation and a turn to technofixes (Ren \& Jóhannesson, 2018). In the same vein the challenges and problems of tourism development cannot be solved or dealt with 
through quick and complete solutions. Tourism as a social force is a process of becoming that we as researchers participate in making. We should focus on finding ways to respond to emergent realities and give voice to the others of tourism.

This leads to the third suggestion - to move along and, in this occasion, with nature. A common understanding of tourism policy making is that it is a human practice played out on a passive stage of nature. In a destination like Iceland nature is the main resource of tourism and the sector is waking up to the fact that it needs to be protected and managed. When tracing the history of tourism policy making in Iceland couple of years ago, I noticed that there were two incidents that stood out as turning points for getting tourism to be recognised as an important sector that needed attention, support and regulation from the authorities. On the one hand, it was cod, the most important export product of the Icelandic fisheries, and, on the other, a volcano eruption (Jóhannesson, 2012, 2015). In 1993 the cod fisheries collapsed which was a huge blow for the economy. The general director of the Icelandic Tourist Board at the time linked the figure of the tourist to the cod arguing that one tourist would bring the same earnings of foreign currency to the national economy as one ton of cod. When asked about the incident he recalled:

... all of a sudden...one afternoon this just became the hot stuff in the debate. All of a sudden this was put in a context that people understood. [...] [...] this was the only way to get people to realize [the economic significance of tourism]. To try to connect it to something ... because people understood cod.

The link to the absent cod was a turning point in securing tourism a presence in discourse on economic development and policy making (Jóhannesson, 2015). Much later, in 2010 a serious work was underway within the ministry of tourism in cooperation with the Icelandic Tourist Board and numerous other, mainly public, stakeholders in revising the tourism policy document at the time. The policy work was taken out of the confines of the ministry and opened up for other actors. This was a notable change meant to improve collaboration across sectors, but it was clear it was hampered by internal tensions and competition (public-private and within the public sector). However, in April 2010 Eyjafjallajökull erupted. As ash particles encountered jet engines in high altitude the order of European air space crumbled. The meeting of ash particles and jet engines is indeed a perfect example of a geo-social relational encounter that had wide ranging repercussions. Icelandic tourism authorities were concerned that this event would have devastating implications for tourism, which at the time was desperately needed as the economy was slowly recovering from financial crisis (Jóhannesson \& Huijbens, 2010). This event pushed public and private actors to collaborate more intensively and together they financed a huge marketing scheme for tourism, Inspired by Iceland. The minister of tourism at the time noted that the event had prompted a culture-change. It created a feeling of solidarity and a fertile ground for more collaboration (Jóhannesson, 2012).

These two very short anecdotes bring us back to the problematic idea of organising freedom. No order is total or durable in finite terms and this is apparent if the agency of the earth is acknowledged, that is, if we recognise and appreciate the dynamics of a world "continually on the boil" (Ingold, 2008, p. 14). And this is what "moving along" urges us to do. We cannot stay put and analyse the world from afar. We are in the midst of things and if we are going to respond to the lively realities of tourism we have to move along. 
Our descriptions should then not try to freeze the world by merely describing it but embrace the process of life and open up our perception to what is going on there so that we, in turn, can respond to it (Ingold, 2013). We have the responsibility to carve out critical connections not by staying distant trying to unmask the real condition of the world but to stay proximate, moving along the relations through which the tourism realities emerge. Critical proximity implies staying empirically close to the subject matter, opening up 'matters of fact' (Jóhannesson, Lund, \& Ren, 2018). As such it demands care: which is "everything that we do to maintain, continue and repair 'our world' so that we can live in it as well as possible" (de la Bellacasa, 2011, p. 93). The notion of care should not be taken as paternal stewardship. Rather it refers to work that seeks improvement and efforts which "are ongoing, adaptive, tinkering and open ended" (Heuts \& Mol, 2013, p. 130).

Importantly, the notion of care does not promise full control or offer a perfect solution. Rather, it outlines means to bring together what seem as separate worlds of research through composition and engagement with tourism imponderables (Jóhannesson, Lund, \& Ren, 2018, p. 47).

At times it may mean to take on the role of distant observer, at other times to become a close co-worker. In relation to nature attending to the Anthropocene is about linking together biographies of humans and more-than-humans, thus reconfiguring how we think and enact tourism.

\section{Concluding remarks}

The concept of the Anthropocene manifest changes in how we think about and understand the relations between nature and society. However, in order to make it meaningful, for instance in the context of tourism research and education, it needs to be brought down to earth. To paraphrase Pálsson and Swanson (2016) we need bold theories rather than big theories to describe what is happening on the ground and thus situate the Anthropocene. We as researchers and educators need to be bold enough to look down, stay with the trouble and move along to improvise liveable futures.

As the examples of cod and volcano bring forth, tourism takes place through topological relations which underlines that there is no final level ordering of the usual building blocks of society or nature but rather "movement - as the ordering of continuity - composes the forms of social and cultural life themselves" (Lury, Parisi, \& Terranova, 2012, p. 6). Therefore, we cannot escape the fate and responsibility to move along with the earth - not to organize our freedom once and for all but to compose our daily existence the best we can - with others.

\section{References}

Berg, M. \& Seeber, B. K. (2016). The slow professor: Challenging the culture of speed in the academy. University of Toronto Press.

Björk. (1997). Hunter. On Homogenic [CD]. London: One Little Indian Records. 
Blok, A. (2010). Topologies of climate change: Actor-network theory, relational-scalar analytics, and carbon-market overflows. Environment and Planning D: Society and Space, 28, 896-912. https://doi.org/10.1068/d0309

de la Bellacasa, M. P. (2011). Matters of care in technoscience: Assembling neglected things. Social Studies of Science, 41(1), 85-106. https://doi.org/10.1177/0306312710380301

Haraway, D. J. (2008). When species meet. Minneapolis, MN: University of Minnesota Press.

Haraway, D. J. (2016). Staying with the trouble: Anthropocene, Capitalocene, Chthulucene. In J. W. Moore (Ed.), Anthropocene or Capitalocene? Nature, history, and the crisis of capitalism (pp. 34-76). Oakland, CA: PM Press.

Heuts, F., \& Mol, A. (2013). What is a good tomato? A case of valuing in practice. Valuation Studies, 1(2), 125-146. https://doi.org/10.3384/vs.2001-5992.1312125

Huijbens, E., \& Gren, M. (2016). Tourism and the Anthropocene: An urgent emerging encounter. In M. Gren \& E. Huijbens (Eds.), Tourism and the Anthropocene (pp. 1-13). London: Routledge.

Ingold, T. (2008). Bringing things to life: Creative entanglements in a world of materials. Retrieved from http://www.reallifemethods.ac.uk/events/vitalsigns/programme/documents/ vital-signs-ingold-bringing-things-to-life.pdf

Ingold, T. (2013). Making: Anthropology, archaeology, art and architecture. London: Routledge.

Jóhannesson, G. T. (2007). Emergent tourism: An actor-network approach to tourism economies. (PhD thesis), Roskilde Universitetscenter.

Jóhannesson, G. T. (2012). Tími til að tengja? Af stefnumótun í ferðapjónustu á Íslandi [Time to connect: On tourism policy in Iceland]. Stjórnmál og Stjórnsýsla, 8(1), 173-193.

Jóhannesson, G. T. (2015). A fish called tourism: Emergent realities of tourism policy in Iceland. In G. T. Jóhannesson, C. Ren, \& R. van der Duim (Eds.), Tourism encounters and controversies: Ontological politics of tourism development (pp. 181-200). Farnham: Ashgate.

Jóhannesson, G. T., \& Huijbens, E. (2010). Tourism in times of crisis: Exploring the discourse of tourism development in Iceland. Current Issues in Tourism, 13, 419-434. https://doi.org/10.1080/ 13683500.2010 .491897

Jóhannesson, G. T., Lund, K. A., \& Ren, C. (2018). Making matter in the midst of things: Engaging with tourism imponderables through research. In C. Ren, G. T. Jóhannesson, \& R. van der Duim (Eds.), Co-creating tourism research: Towards collaborative ways of knowing (pp. 39-54). London: Routledge.

Jóhannesson, G. T., Ren, C., \& van der Duim, R. (2016). ANT, tourism and situated globality: Looking down in the Anthropocene. In M. Gren \& E. Huijbens (Eds.), Tourism and the Anthropocene (pp. 77-93). London: Routledge.

Latour, B. (1993). We have never been modern (C. Porter, Trans.). Cambridge: Harvard University Press.

Latour, B. (2002). Aramis or the love oftechnology (C. Porter, Trans.). Cambridge: Harvard University Press. 
Latour, B. (2004). Why has critique run out of steam? From matters of fact to matters of concern. Critical Inquiry, 30, 225-248.

Latour, B. (2005). Reassembling the social: An introduction to actor-network-theory. Oxford University Press.

Latour, B. (2017). Down to earth: Politics in the new climatic regime (C. Porter, Trans.). Cambridge: Polity.

Lund, K. A., \& Benediktsson, K. (2011). Inhabiting a risky earth. Anthropology Today, 27(1), 6-9. https://doi.org/10.1111/j.1467-8322.2011.00781.x

Lury, C., Parisi, L., \& Terranova, T. (2012). Introduction: The becoming topological of culture. Theory, Culture \& Society, 29(4/5), 3-35. https://doi.org/10.1177/0263276412454552

Malinowski, B. (1984). Argonauts of the Western Pacific. Prospect Heights: Waveland Press.

Prahalad, C. K., \& Ramaswamy, V. (2004). Co-creation experiences: The next practice in value creation. Journal of Interactive Marketing, 18(3), 5-15. https://doi.org/10.1002/dir.20015

Pálsson, G. (1995). The textual life of savants: Ethnography, Iceland, and the linguistic turn. Chur: Harwood Academic Publishers.

Pálsson, G. (1996). Human-environmental relations: Orientalism, paternalism and communalism. In P. Descola \& G. Pálsson (Eds.), Nature and society: Anthropological perspectives (pp. 63-81). London: Routledge.

Pálsson, G., \& Swanson, H. A. (2016). Down to earth: Geosocialities and geopolitics. Environmental Humanities, 8(2), 149-171. https://doi.org/10.1215/22011919-3664202

Ren, C., \& Jóhannesson, G. T. (2018). Collaborative becoming: Exploring tourism knwoledge collectives. In C. Ren, G. T. Jóhannesson, \& R. van der Duim (Eds.), Co-creating tourism research: Towards collaborative ways of knowing (pp. 24-38). London: Routledge.

van der Duim, R., Jóhannesson, G. T., \& Ren, C. (2018). Balancing values: Co-creation in and out of academia. In C. Ren, G. T. Jóhannesson, \& R. van der Duim (Eds.), Co-creating tourism research: Towards collaborative ways of knowing (pp. 11-23). London: Routledge.

van der Duim, R., Ren, C., \& Jóhannesson, G. T. (Eds.) (2012). Actor-network theory and tourism: Ordering, materiality and multiplicity. London \& New York: Routledge. 